\title{
Investigating the Applicability of the Imperialist Competitive Algorithm in the Problem of Allocating Trucks to an Open Pit Mine
}

The Mining-Geology-Petroleum Engineering Bulletin UDC: 622.2:62-93

DOI: 10.17794/rgn.2019.2.4

Original scientific paper

\author{
Ali Dabbagh; Raheb Bagherpour \\ Department of Mining Engineering, Isfahan University of Technology, Isfahan 8415683111, Iran
}

\begin{abstract}
Due to high transportation costs in open pit mines, various optimization methods have been developed in this field. Using these methods is much simpler in homogeneous fleets than heterogeneous fleets and it is better to use metaheuristic methods in heterogeneous systems. The number of trucks allocated to each loading device in an iron ore mine was determined in this study using the imperialist competitive algorithm, and with the aim of increasing production in a heterogeneous environment. Then, to determine the amount of production according to the distribution functions which relate to the time cycles, the transportation fleet was simulated and the problem was solved. Iron ore production in the simulated model was increased by $4.4 \%$ and the waste rock by $4.1 \%$. In this optimization process, there was also better control over the production amount of iron containing the intrusive element, phosphor.
\end{abstract}

\section{Keywords:}

open pit mine, loading, haulage, Imperialist Competitive Algorithm, allocation

\section{Introduction}

The main purpose of a mining activity is the production of minerals for the consumption of the community. If the activity is successful, the production of minerals will be performed at the lowest cost, and the remaining profit will be spent on mining development and ore extraction. One of the important parameters in each mine is the choice of machinery and its adaptation. In general, the choice of machinery is made in order to achieve a specific goal, and the selected machinery must be adapted appropriately to the working environment and other equipment. The selection of machinery is based on the constraints that must be taken into account in any mine. The unit operations of an open pit mine include drilling, blasting, loading and haulage. Among them, the highest cost of open pit mining is related to loading and haulage, respectively (Hartman, 2002). Therefore, the study of the relationship between loading and haulage devices can be considered as the most important priority in each mine.

Different methods and algorithms are presented for optimization, each with its own advantages and disadvantages. In this research, we are going to investigate the applicability of the imperialist competitive algorithm in the system of allocating trucks to loading devices.

\section{Literature}

Considering the importance of transportation in open pit mines, various methods have been proposed to opti-

Corresponding author: Raheb Bagherpour

bagherpour@cc.iut.ac.ir mize the transportation fleet. Optimizations are usually based on mathematical and operations research procedures. "Truck allocation and truck dispatching are two separate processes" (Ta et al., 2013). The first is that a certain number of trucks are allocated to each loading device and, until the end of the shift, the number of trucks which have been allocated to the loader is fixed and determined. This method is called the allocation method. In the second, the number of dedicated trucks is not fixed. In this case, the truck requests a route when it arrives at the decision point. After the truck requests the route, it is ordered to which machine it should go for loading. This system is referred to as dispatching. Except for these two methods, there are others, such as optimization in the choice of machinery, optimization in purchasing, decision in replacing the machinery, etc. The optimization step begins after deciding on its type. There are several ways to optimize, as shown in Table 1.

The studies which have been performed for optimization are mainly based on integer linear programming, queuing theory and simulation, and rarely use metaheuristic techniques due to the fact that functions are not linear in many cases, especially in heterogeneous fleets, (Ta et al., 2013; Burt, 2008). When working conditions change due to machine failures, and linear programming is based on fixed conditions (Zhang \& Xia, 2015), which makes it difficult to optimize the distribution system by using linear programming. The use of queuing theory and simulation of transport operations can be very useful in the distribution system of a truck in a mine. Using the Markov decision-making process, the allocation of the trucks to 
Table 1: Different methods of optimization in open-pit mine transport fleet

\begin{tabular}{|c|c|}
\hline Method & References \\
\hline $\begin{array}{l}\text { Use of linear } \\
\text { programming } \\
\text { and integer linear } \\
\text { programming }\end{array}$ & $\begin{array}{c}\text { (Ta et al., 2013; Rodrigio et al., } \\
\text { 2013; Zhang \& Xia, 2015; } \\
\text { Makui et al., 2010; } \\
\text { Subtil et al., 2011) }\end{array}$ \\
\hline $\begin{array}{l}\text { Use of queuing theory } \\
\text { and simulation }\end{array}$ & $\begin{array}{l}\text { (Delasay et al., 2012; Bascetin } \\
\text { \& Ercebeli, 2009; Musingwini } \\
\text { \& Krause, 2007; Kaba et al., 2014; } \\
\text { Kang et al., 2006; Sattarvand } \\
\text { \& Hashemi, 2014; } \\
\text { Arroyo Ortiz et al., 2013) }\end{array}$ \\
\hline $\begin{array}{l}\text { Use of metaheuristic } \\
\text { methods such as } \\
\text { genetic algorithm, ant } \\
\text { colony algorithm, etc. }\end{array}$ & $\begin{array}{c}\text { (Kakaee et al., 2011; He et al., } \\
\text { 2010; Bissiri, 2002) }\end{array}$ \\
\hline Use of match factor & $\begin{array}{c}\text { (Arroyo Ortiz et al., 2013; Morgan } \\
\text { \& Peterson, 1986; Burt, 2008; } \\
\text { Nel et al., 2011) }\end{array}$ \\
\hline $\begin{array}{l}\text { Use of monitoring } \\
\text { and automation to } \\
\text { control the fleet and } \\
\text { identify weaknesses } \\
\text { of the system }\end{array}$ & $\begin{array}{c}\text { (Cetin, 2004; Gu et al., 2008; } \\
\text { Lizotte et al., 1987; Yavari et al., } \\
\text { 2005; Douglas, 1964) }\end{array}$ \\
\hline
\end{tabular}

the shovel was investigated in a heterogeneous state. Due to the complexity of the problem, it was only solvable for two shovels (Delasay et al., 2012). In a coal mine and in homogeneous conditions, the best route for trucks was obtained using simulation. After that, the optimal number of trucks was determined by using an integer linear programming model (Bascetin \& Ercebeli, 2009). ARNA software was used to simulate a fleet of vehicles in a mine to determine the number of trucks needed for each loader (Kang et al., 2006). A comparison between the allocation and dispatching of trucks between shovels in the Sungun copper mine was carried out by using simulation in ARNA software (Sattarvand \& Hashemi, 2014). The match factor was developed in two homogeneous and heterogeneous modes (Morgan \& Peterson, 1986; Burt, 2008). This factor indicates the idle probability of the loading or haulage devices. With the use of a genetic algorithm, the applicability of the problem of the trucks' allocation to the loaders was examined (He et al., 2010). This study was completely theoretical and was not evaluated for a real mine. The ability to use the ant colony algorithm was developed in the dispatching of the trucks between shovels (Bissiri, 2002). This study was also not evaluated for a real mine. Using the imperialist competitive algorithm to optimize the allocation system of the truck to the loading device is a new procedure among the studies in this field.

\section{Imperialist competitive algorithm}

In this study, the imperialist competitive algorithm (ICA) has been used to determine the number of trucks

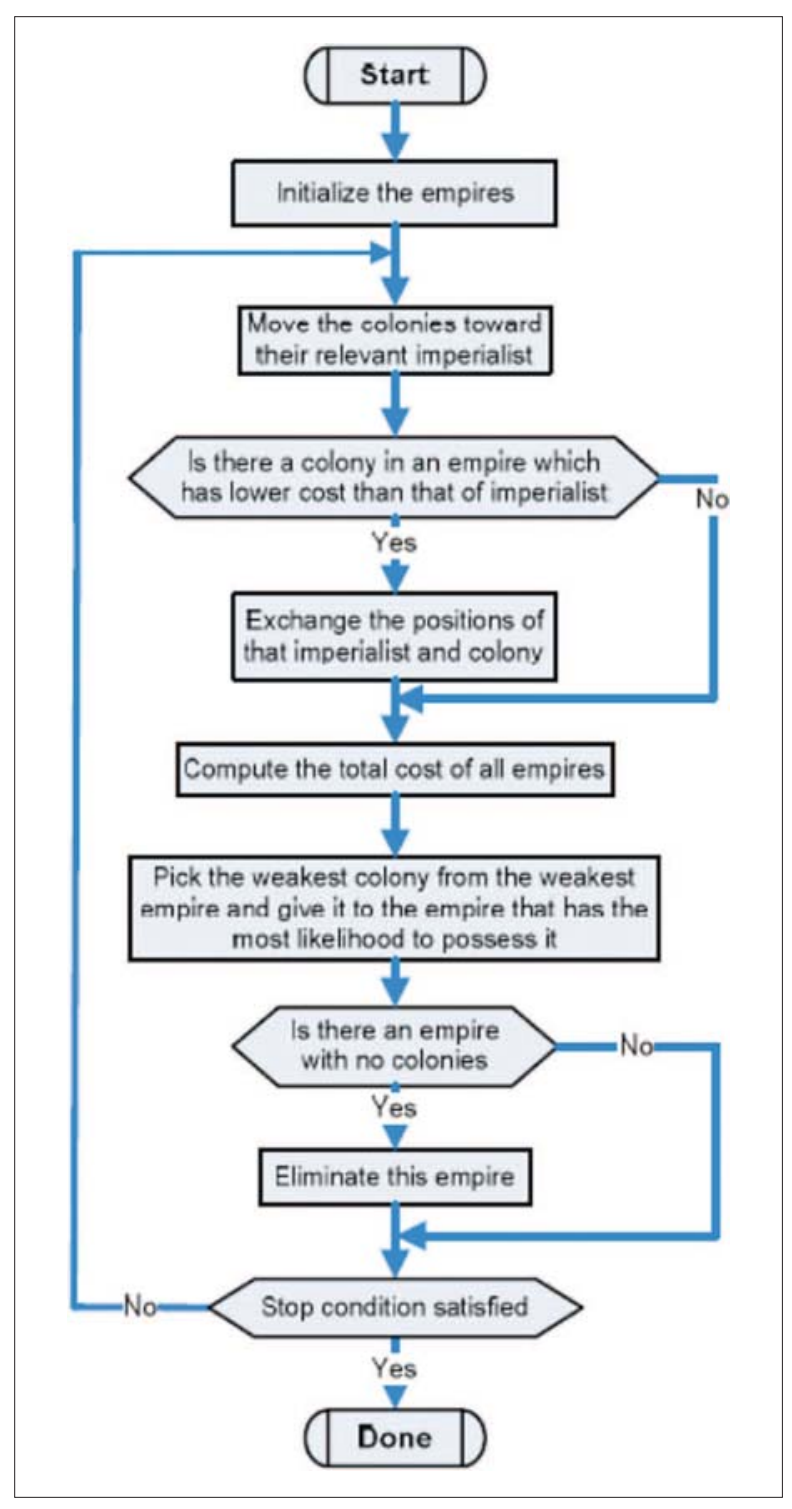

Figure 1: Flowchart of the imperialist competitive algorithm (Atashpaz-Gargari \& Lucas, 2007)

which have been allocated to each loading device. ICA was presented, inspired by socio-political processes (Atashpaz-Gargari \& Lucas, 2007). This algorithm also begins with a random primitive population similar to population-cantered algorithms, each individual of which is called a "country". Given the objective function of the problem, some of the best countries are selected as imperialists who try to colonize the rest of the world. The collection of the imperialist and its colonies is called an "empire". With its power, the imperialist attracts the colonies and the colonies resist it. The power of each empire depends on its two constituent parts, namely, the imperialist and its colonies. With the formation of primitive empires, imperialist rivalry begins between them, and every empire that fails to compete in colonialism or to increase its power, will be eliminated gradually. In 
Table 2: Name of loading device and specifications of the transportation route in the iron ore mine

\begin{tabular}{|c|c|c|c|c|}
\hline Location of the loading & Loading device & $\begin{array}{c}\text { Machine } \\
\text { name }\end{array}$ & $\begin{array}{c}\text { Location of } \\
\text { unloading }\end{array}$ & \begin{tabular}{|c|}
$\begin{array}{c}\text { Distance to location } \\
\text { of unloading }(\mathrm{m})\end{array}$ \\
\end{tabular} \\
\hline Waste work in front of level 1068.5 & Loader with a capacity of $4.2 \mathrm{~m}^{3}$ & L1 & SE Waste Dump & 4680 \\
\hline Iron ore work in front of level 919 & Excavator with a capacity of $4.5 \mathrm{~m}^{3}$ & B-1-4.5 & Main crusher & 3393 \\
\hline Waste work in front of level 979 & Loader with a capacity of $4.2 \mathrm{~m}^{3}$ & L2 & SW Waste Dump & 4460 \\
\hline Waste work in front of level 979 & Excavator with a capacity of $3.4 \mathrm{~m}^{3}$ & B-2-3.4 & SW Waste Dump & 4265 \\
\hline Waste work in front of level 991 & Excavator with a capacity of $2.2 \mathrm{~m}^{3}$ & B-3-2.2 & SW Waste Dump & 4066 \\
\hline Waste work in front of level 1006 & Loader with a capacity of $4.2 \mathrm{~m}^{3}$ & L3 & SW Waste Dump & 3905 \\
\hline $\begin{array}{l}\text { High-phosphor iron ore work } \\
\text { in front of level } 928.5\end{array}$ & Excavator with a capacity of $3.4 \mathrm{~m}^{3}$ & B-4-3.4 & $\begin{array}{l}\text { High-phosphor } \\
\text { iron ore crusher }\end{array}$ & 3727 \\
\hline $\begin{array}{l}\text { High-phosphor iron ore work } \\
\text { in front of level } 928.5\end{array}$ & Excavator with a capacity of $3.4 \mathrm{~m}^{3}$ & B-5-3.4 & $\begin{array}{l}\text { High-phosphor } \\
\text { iron ore dump }\end{array}$ & 3586 \\
\hline
\end{tabular}

this case, other imperialists take its place, or even a colony may become a colonizer. Therefore, the survival of an empire is dependent on its power in moving colonies toward their relevant imperialist and to dominate them. Consequently, during the imperialist rivalries, the power of the larger empires will gradually be increased and the weaker empires will be eliminated. Empires will develop their own colonies to increase their power. Over time, the colonies will be closer to the imperialist in power, and we will see a kind of convergence in the solution of the problem. The ultimate colonial competition is when there is a single empire in the world. In this empire, colonies are very close to the imperialist in terms of power.

The steps for solving the problem are as follows (Atashpaz-Gargari \& Lucas, 2007):

a - Generating initial empires

b - Moving the colonies of an empire toward the imperialist

$\mathrm{c}-$ Exchanging positions of the imperialist and a colony

d - Total power of an empire

e - Imperialistic competition

f - Eliminating the powerless empires

$\mathrm{g}$ - Convergence

The problem solution flowchart along with the imperialist competitive algorithm has been shown in Figure 1.

\section{Solving the problem of allocating trucks to the excavator using the imperialist competitive algorithm}

Optimization of the transportation fleet is based on various goals. These goals could include minimizing costs, maximizing production, reducing waiting times, and so on. It is necessary to consider the constraints of the problem and the executive conditions in addition to goal setting. In the following chapter, the details of the mine and the work procedure are examined. The optimization goal in this research is to allocate a truck to the loading device in such a way that the production of ore and waste is maximized, and that the production of ore does not exceed the capacity of the crusher.
Table 3: The distribution function of the truck unloading, in seconds

\begin{tabular}{|l|c|c|c|c|c|}
\hline $\begin{array}{l}\text { Location of } \\
\text { unloading }\end{array}$ & $\begin{array}{c}\text { Distribution } \\
\text { function }\end{array}$ & Min & Max & Average & $\begin{array}{c}\text { Standard } \\
\text { deviation }\end{array}$ \\
\hline Crusher & Normal & 42 & 71 & 55.2 & 4.1 \\
\hline Dump & Triangle & 39 & 61 & 49.1 & 3.1 \\
\hline
\end{tabular}

\subsection{Specifications of the transportation fleet}

A real iron ore mine was selected for the study in the centre of Iran and field surveys were carried out. The annual production of the mine is 4 million tons and the ratio of stripping was 1.6. In this mine, three $4.2 \mathrm{~m}^{3}$ loaders, one $2.2 \mathrm{~m}^{3}$ excavator, three $3.4 \mathrm{~m}^{3}$ excavators, one $4.5 \mathrm{~m}^{3}$ excavator, twenty three 35 -ton dump trucks, and four 50-ton dump trucks were being used. In Table 2, the name of the loading device, the location of the loading, and the characteristics of the transportation route are shown.

The distribution function of the speed of a truck was measured with 560 extractions in two modes. The distribution function of the speed of the loaded truck was normalized with a mean of $9.33 \mathrm{~m} / \mathrm{s}$ and a standard deviation of $1.3 \mathrm{~m} / \mathrm{s}$ and the distribution function of the speed of the empty truck was normalized with a mean of 14.3 $\mathrm{m} / \mathrm{s}$ and a standard deviation of $1.34 \mathrm{~m} / \mathrm{s}$. The required time for manoeuvring and unloading into a crusher or waste dumping was obtained with 143 extractions as described in Table 3.

With 1285 extractions, the load distribution function of the truck, including the manoeuvring time for placing the truck next to the loading device and the time the truck was loaded by the loader, was measured according to Table 4. The required time for the dispatch and return of the trucks is obtained by driving the carrying distance at the traveling speed. In Table 5, the distribution functions of travel times of the haulage devices are given.

It is necessary to estimate the amount of production of each loading device after determining the cycle times. To do this, it is necessary to calculate the probability of idling for each loading device. Equation 1 computes the 
Table 4: Distribution function of the manoeuvring times for placing a truck next to a loader and the loading time of the truck

\begin{tabular}{|c|c|c|c|c|c|}
\hline Loading device & Rock type & $\begin{array}{l}\text { Truck capacity } \\
\text { (ton) }\end{array}$ & Distribution function & Average (s) & $\begin{array}{c}\text { Standard } \\
\text { deviation (s) }\end{array}$ \\
\hline \multirow{2}{*}{$\begin{array}{l}\text { Loader with a capacity } \\
\text { of } 4.2 \mathrm{~m}^{3}\end{array}$} & \multirow{2}{*}{ waste } & 35 & Normal & 176 & 31.2 \\
\hline & & 50 & Normal & 216 & 45.3 \\
\hline \multirow{2}{*}{$\begin{array}{l}\text { Excavator with a capacity } \\
\text { of } 4.5 \mathrm{~m}^{3}\end{array}$} & \multirow[t]{2}{*}{ Iron ore } & 35 & $\beta(2.01,1.97)$ & 194 & 27.3 \\
\hline & & 50 & $\beta(3.48,1.55)$ & 234 & 39.1 \\
\hline \multirow{2}{*}{$\begin{array}{l}\text { Excavator with a capacity } \\
\text { of } 2.2 \mathrm{~m}^{3}\end{array}$} & \multirow[t]{2}{*}{ waste } & 35 & Normal & 192 & 32.3 \\
\hline & & 50 & Triangle & 225 & 44.9 \\
\hline \multirow{2}{*}{$\begin{array}{l}\text { Excavator with a capacity } \\
\text { of } 3.4 \mathrm{~m}^{3}\end{array}$} & \multirow{2}{*}{$\begin{array}{l}\text { High-phosphor } \\
\text { iron ore }\end{array}$} & 35 & Normal & 124 & 27.8 \\
\hline & & 50 & Normal & 169 & 38.9 \\
\hline \multirow{2}{*}{$\begin{array}{l}\text { Excavator with a capacity } \\
\text { of } 3.4 \mathrm{~m}^{3}\end{array}$} & \multirow[t]{2}{*}{ waste } & 35 & Erlang $(23.8,2)$ & 166 & 42.1 \\
\hline & & 50 & Weibull(37.6,1.26) & 214 & 55.8 \\
\hline
\end{tabular}

Table 5: The distribution function of the dispatch and return of the truck

\begin{tabular}{|c|c|c|c|c|c|c|}
\hline \multirow[b]{2}{*}{ The beginning of the route } & \multirow[b]{2}{*}{ The end of the route } & \multirow[b]{2}{*}{$\begin{array}{l}\text { Distribution } \\
\text { function }\end{array}$} & \multicolumn{2}{|c|}{ The route there (s) } & \multicolumn{2}{|c|}{ The route back (s) } \\
\hline & & & Average & $\begin{array}{l}\text { Standard } \\
\text { deviation }\end{array}$ & Average & $\begin{array}{l}\text { Standard } \\
\text { deviation }\end{array}$ \\
\hline Waste work in front of level 1068.5 & SE Waste Dump & Normal & 511 & 77.4 & 331 & 33.3 \\
\hline Iron ore work in front of level 919 & Main crusher & Normal & 371 & 56.1 & 240 & 24.1 \\
\hline Waste work in front of level 979 & SW Waste Dump & Normal & 487 & 73.9 & 316 & 31.8 \\
\hline Waste work in front of level 979 & SW Waste Dump & Normal & 465 & 70.6 & 301 & 30.3 \\
\hline Waste work in front of level 991 & SW Waste Dump & Normal & 444 & 67.4 & 288 & 29 \\
\hline Waste work in front of level 1006 & SW Waste Dump & Normal & 427 & 64.7 & 276 & 27.8 \\
\hline $\begin{array}{l}\text { High-phosphor iron ore work } \\
\text { in front of level } 928.5\end{array}$ & $\begin{array}{l}\text { High-phosphor iron } \\
\text { ore crusher }\end{array}$ & Normal & 407 & 61.8 & 264 & 26.5 \\
\hline $\begin{array}{l}\text { High-phosphor iron ore work } \\
\text { in front of level } 928.5\end{array}$ & $\begin{array}{l}\text { High-phosphor } \\
\text { iron ore dump }\end{array}$ & Normal & 392 & 59.4 & 254 & 25.5 \\
\hline
\end{tabular}

match factor of the trucks which has been allocated to the loading devices according to their numbers (Burt, 2008).

$$
M F_{i},=\frac{\sum_{i}\left(t_{i, i}, \times x_{i}\right)}{\bar{t}_{X} \times x_{i}}
$$

Where:

$M F_{i}$, - is the match factor,

$t_{i, i}, \quad-$ is the time of loading the truck type $\mathrm{i}$ by the loader type $i$,

$x_{i} \quad-$ is the number of truck type $i$,

$x_{i}, \quad-$ is the number of loader type $i$,

$\overline{t_{x}} \quad$ is the average time of all the trucks' haulage cycle.

This variable is called the match factor and it is a ratio that represents the rate of the arrival of the haulage device to the loader servicing rate. This quantity depends on the capacity of the equipment and the times of the loading and haulage cycle. If this factor is equal to one, it means that the idle probability of devices (loaders and trucks) is zero. If the match factor is less than one, it means that the loading device waits for the truck (there is a probability of idleness of the loaders) and if this factor is more than one, the truck is in the queue for services of the loader (there is a probability of idleness of the trucks) (Burt, 2008). The match factor is calculated separately for each loader device. Here $x_{i}$, equals 1 .

For example, if the match factor is 0.8 , we expect the loader to be waiting $20 \%$ of the time for the truck and if the coefficient is 1.2 , we expect the truck to be waiting $20 \%$ of the time for the loader. In this case, the match factor for each loading device is calculated with respect to the number of trucks which has been allocated to it individually.

If $m_{l i}$, is the production power of a loading device in one hour of useful work and the matching coefficient is

Table 6: The average production power of each device in one hour of useful work

\begin{tabular}{|l|c|c|}
\hline Loading device & Rock type & $m_{l,}($ ton/h $)$ \\
\hline $\begin{array}{l}\text { Loader with a capacity } \\
\text { of } 4.2 \mathrm{~m}^{3}\end{array}$ & waste & 701 \\
\hline $\begin{array}{l}\text { Excavator with a capacity } \\
\text { of } 4.5 \mathrm{~m}^{3}\end{array}$ & Iron ore & 969 \\
\hline $\begin{array}{l}\text { Excavator with a capacity } \\
\text { of } 2.2 \mathrm{~m}^{3}\end{array}$ & waste & 612 \\
\hline $\begin{array}{l}\text { Excavator with a capacity } \\
\text { of } 3.4 \mathrm{~m}^{3}\end{array}$ & $\begin{array}{c}\text { High-phosphor } \\
\text { iron ore }\end{array}$ & 875 \\
\hline $\begin{array}{l}\text { Excavator with a capacity } \\
\text { of } 3.4 \mathrm{~m}^{3}\end{array}$ & waste & 712 \\
\hline
\end{tabular}


greater than or equal to one, then we expect the production of a loading device is $m_{l i}$, again. If the matching coefficient is less than one, the expected production of the loading device is obtained by Equation 2.

$$
m_{l d i}=M F_{i}, \times m_{l i}
$$

With the extraction in the mine, the average production power of each loading device per hour of useful work is given in Table 6.

\subsection{Making the primary countries to solve the model}

As mentioned before, there are twenty three trucks with a capacity of 35-tons each in the mine. There are also four 50-ton trucks and eight loading devices. In making the primary countries, equations 3 to 7 should always hold. Relationship 7 is true when the match factor for each loading device is less than or equal to one.

$$
\begin{aligned}
& 0 \leq n_{i^{\prime}} \leq 23 \quad \forall i^{\prime}=1,2, \ldots, 8 \\
& 0 \leq m_{i^{\prime}} \leq 4 \quad \forall i^{\prime}=1,2, \ldots, 8 \\
& \sum_{i^{\prime}=1}^{i^{\prime}=8} n_{i^{\prime}}=24 \\
& \sum_{i^{\prime}=1}^{i^{\prime}=8} m_{i^{\prime}}=4 \\
& \left(n_{i^{\prime}}+m_{i^{\prime}}\right) \leq N t_{i^{\prime}} \text { or } M F_{i^{\prime}} \leq 1
\end{aligned}
$$

Where:

$n_{i}$, $\quad$ is the number of 35 -ton trucks allocated to the loading device $i$ '.

$m_{i}$, - is the number of 50-ton trucks allocated to the loading device $i$ '.

$N t_{i}$, - is the maximum number of trucks that can be allocated to the loading device $i$ '.

Therefore, to make a random answer, it is necessary to select eight random numbers from 0 to 23 , and eight random numbers from 0 to 4 , provided that they are consistent with the results from equations 3 to 7. In this way, 50

Table 7. A random country produced

\begin{tabular}{|l|c|c|c|}
\hline \multirow{2}{*}{$\begin{array}{l}\text { Loading } \\
\text { device }\end{array}$} & \multicolumn{2}{|c|}{$\begin{array}{c}\text { Number of trucks assigned to each } \\
\text { loading device }\end{array}$} & \multirow{2}{*}{$M F_{i^{\prime}}$} \\
\cline { 2 - 3 } & $n_{i^{\prime}}$ & $m_{i^{\prime}}$ & \\
\hline L1 & 3 & 1 & 0.61 \\
\hline B-1-4.5 & 5 & 0 & 0.98 \\
\hline L2 & 4 & 0 & 0.63 \\
\hline B-3-2.2 & 3 & 1 & 0.73 \\
\hline B-2-3.4 & 2 & 0 & 0.26 \\
\hline L3 & 2 & 0 & 0.38 \\
\hline B-4-3.4 & 4 & 2 & 0.81 \\
\hline B-5-3.4 & 0 & 0 & 0 \\
\hline Total & $\sum_{i^{\prime}=1}^{i^{\prime}=8} n_{i^{\prime}}=23$ & $\sum_{i^{\prime}=1}^{i^{\prime}=8} m_{i^{\prime}}=4$ & \\
\hline
\end{tabular}

random countries are created to solve the problem. Among these 50 countries, 6 are colonizers and 44 are colonies. The problem of assigning trucks to a loader has not been resolved before with the imperialist competitive algorithm. On the other hand, this algorithm works on the basis of random answers. So, the number of countries, colonies and colonizers is randomly selected to start work. An example of a country is given in Table 7.

\subsection{Method of determining the value of each country}

The index which has been used to evaluate the costs and earnings of the mine is as follows.

- The cost of the extraction of iron ore per ton: 3.2 Euros

- The cost of extracting wastes per ton: 2.9 Euros

- The cost of the grinding and processing of highphosphor iron ore per ton: 7 Euros

- The cost of the crushing and grading of low-phosphor iron ore per ton: 3 Euros

- Sales price of iron concentrate per ton: 45 Euros

- Sales price of grained iron ore per ton: 32 Euros

- The extraction ratio of high-phosphor iron ore per ton: 2 (to produce one ton of iron ore concentrate it is necessary to extract two tons of high-phosphor iron ore).

Considering the above numbers, the expected profit from the sale of one ton of grained iron ore is 31.6 Euros and the expected profit from the sale of one ton of highphosphor iron ore (considering the grinding and processing costs) is 22.6 Euros regardless of the stripping ratio.

The actual capacity of the main crusher and highphosphor ore crusher in the mine is 800 tons per hour each. The main objective of this optimization is to increase the work efficiency of the equipment so that with an increase in the production of ore and waste, the production of ore does not exceed the capacity of the crusher. In this regard, the value index of the solution is calculated as follows.

- Economic index of production per ton of production in the loading machine B-1-4.5 is 31.6 Euros for up to 800 tons per hour, and an excess above 800 tons involves a fine of -3.2 Euros/ton of low phosphor iron ore.

- Economic index of production per ton of production in loading both machines B-4-3.4 and B-5-3.4 is 22.6 Euros for up to 800 tons per hour, and an excess above 800 tons involves a fine of -3.2 Euros/ ton of high phosphor iron ore.

- Economic index of stripping (production from other loading devices) per ton of wastes is 2.9 Euros.

The sum of the above is the economic index of each solution. If this index is negative, then the solution is removed from the problem and another country will be created instead. Since the imperialist competitive algo- 


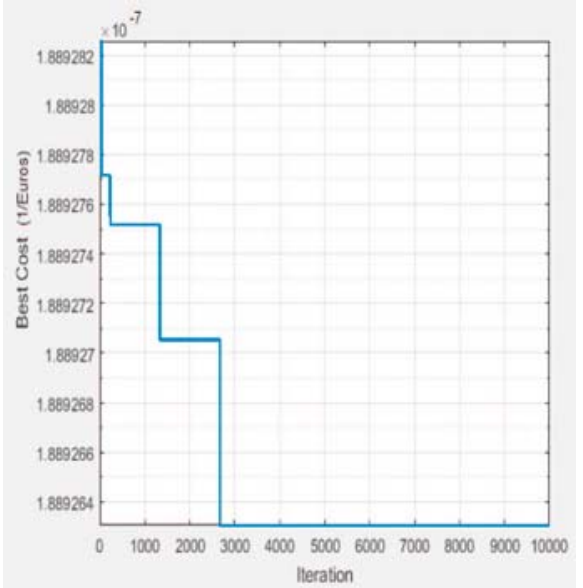

Figure 2. Diagram of the stages of solving the model of the truck allocation to the loading device using the imperialist competitive algorithm rithm is a minimization algorithm, it is necessary to minimize the inverse of this index.

\subsection{Solving the problem}

As previously stated, 50 solutions were considered for the early countries. Programming was done by MATLAB R2011 software. In Figure 2, the optimization process is shown. In this case, optimization steps are staggered. The steps for optimization increase in each step. Therefore, it is likely to change after a large number of repetitions. In order to ensure the desire to respond to optimization, the algorithm loop was repeated 10,000 times. As seen in the figure, the optimum solution was returned after 2764 repetitions.

After determining the number of required trucks for each loading device by the imperialist competitive algorithm, and considering the statistical information on the cycles and the number and capacity of the transport fleet,

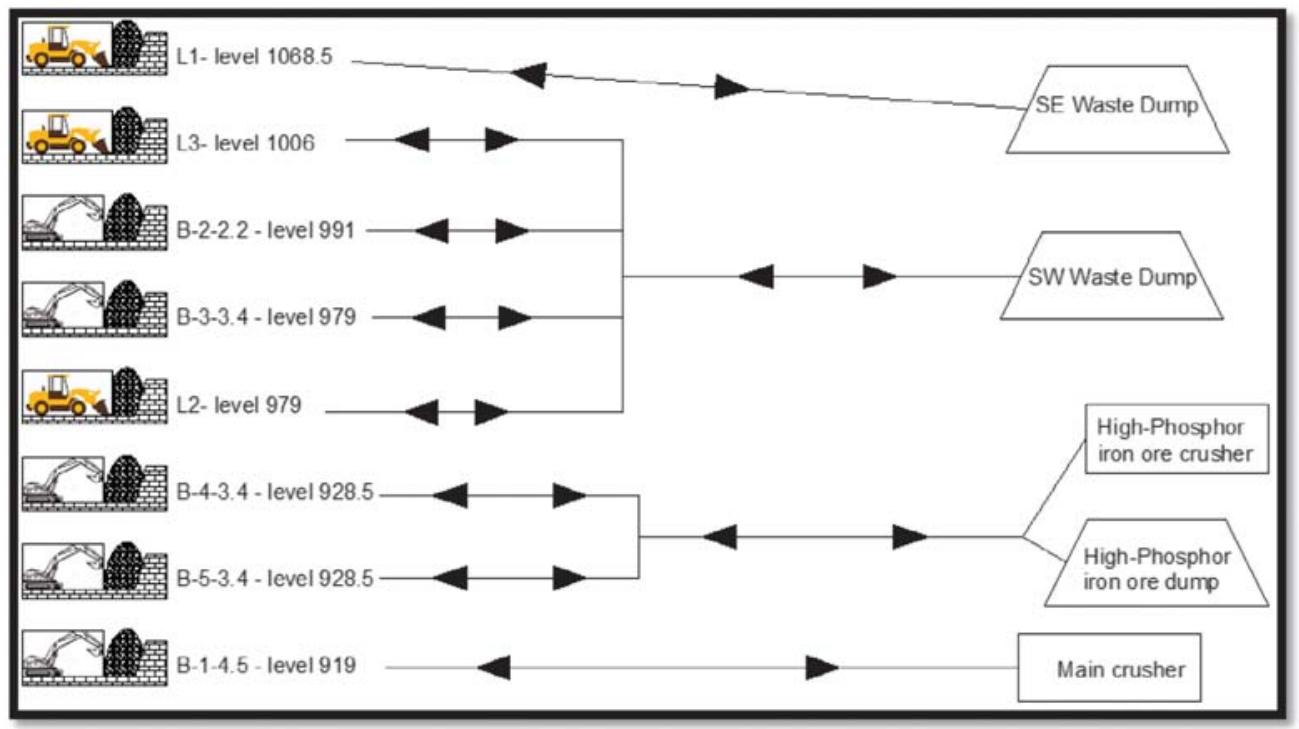

Figure 3. The routes for a simulated model of the transportation fleet

Table 8. Comparison between the number of trucks allocated to each loading device and the amount of production of actual useful work per hour in the mine and optimized by the imperialist competitive algorithm.

\begin{tabular}{|l|c|c|c|c|c|c|c|}
\hline \multirow{2}{*}{$\begin{array}{l}\text { Loader } \\
\text { device } \\
\text { name }\end{array}$} & Rock & $\begin{array}{c}\text { The number of } \\
35 \text { ton Trucks } \\
\text { allocated }\end{array}$ & $\begin{array}{c}\text { The number of } \\
50 \text { ton Trucks } \\
\text { allocated }\end{array}$ & $\begin{array}{c}\text { Production } \\
\text { (ton/h) }\end{array}$ & $\begin{array}{c}\text { The number of } \\
35 \text { ton Trucks } \\
\text { allocated }\end{array}$ & $\begin{array}{c}\text { The number of } \\
50 \text { ton Trucks } \\
\text { allocated }\end{array}$ & $\begin{array}{c}\text { Production } \\
\text { (ton/h) }\end{array}$ \\
\hline L1 & Waste & 3 & 1 & 415 & 3 & 0 & 385 \\
\hline B-1-4.5 & Iron ore & 3 & 2 & 565 & 4 & 2 & 675 \\
\hline L2 & Waste & 2 & 0 & 387 & 3 & 0 & 490 \\
\hline B-2-3.4 & Waste & 2 & 1 & 450 & 3 & 0 & 420 \\
\hline B-3-2.2 & Waste & 2 & 0 & 280 & 2 & 0 & 280 \\
\hline L3 & Waste & 3 & 0 & 420 & 3 & 0 & 455 \\
\hline B-4-3.4 & $\begin{array}{c}\text { High Phosphor } \\
\text { iron ore }\end{array}$ & 4 & 0 & 385 & 3 & 1 & 415 \\
\hline B-5-3.4 & $\begin{array}{c}\text { High Phosphor } \\
\text { iron ore }\end{array}$ & 4 & 0 & 525 & 2 & 1 & 450 \\
\hline
\end{tabular}


the simulation of the transport fleet was carried out to determine the amount of production (see Figure 3). In Table 8, the number of trucks which have been allocated to each loading device and the production expected from each loading device are shown for the two modes of before optimization (actually in the mine) and after optimization (production simulation).

As can be seen, the production of low-phosphor iron ore increased by 110 tons per hour, the production of high-phosphor iron ore decreased by 45 tons per hour, and the stripping increased by 80 tons per hour. Ore extraction increased by $4.4 \%$ and the stripping increased by $4.1 \%$.

\section{Conclusion}

Transportation is the most expensive part of mining in open pit mines, and special attention has to be paid to it. In heterogeneous fleets, solving problems is more complicated and exact mathematical methods cannot easily solve the problem. Therefore, it is necessary to consider the use of metaheuristic methods. The use of the intuitive method of ICA in the problem of allocating trucks to a loading device in a real mine with a heterogeneous transport fleet was aimed at increasing production, and the results were as follows:

- The ICA algorithm was able to increase the production of ore by $4.4 \%$ and waste by $4.1 \%$.

- Considering the fine for excessive production, this method was able to better control the iron ore that had phosphor impurities.

- In the simulated model based on the ICA algorithm, the production of low-phosphor iron ore increased by 110 tons per hour, the production of high-phosphor iron ore decreased by 45 tons per-hour, and the rate of stripping was increased by 80 tons per hour in comparison to the actual conditions of the mine.

\section{References}

Arroyo Ortiz, C. E., Curi, A., \& Campos, P. H. (2013): The use of simulation in fleet selection and equipment sizing in mining. In: Dresden. Singhal, R. and Drebensted, C. (eds.): 22th Mine planning and equipment selection. - Springer Publ. Co., 869-877 p. doi:10.1007/978-3-319-02678-7_84

Atashpaz-Gargari, E., \& Lucas, C. (2007): Imperialism competitive algorithm: An algorithm for optimization inspired by imperialistic competitive. In: Singapore. Chen, Z. (eds.): IEEE Congress on Evoluating Computation. - IEEE Publ. Co., 4661-4667 p. doi: 10.1109/CEC.2007.4425083.

Bascetin, S. G., and Ercebeli, A. (2009): Optimization of shovel-truck system for surface mining . Southern African institute of mining and metallurgy, 109, 433-439.

Bissiri, Y. (2002): Swarm -Based Truck-Shovel Dispatching System in Open Pit Mine Operations. Ph.D. Thesis, Mining and mineral process tengineering, University of British Columbia, Vancouver. 36-64 p.
Burt, C. N. (2008): An optimization approach to materials handling in surface mines. Ph.D. Thesis, Curtin University of Technology. 36-45 p.

Cetin, N. ( 2004): Open-pit truck/shovel haulage system simulation. Ph.D. Thesis, School of natural and applied sciences, Middle East Technical University., Ankara. 26-60 p.

Delasay, M., Kolfal, B., \& Ingolfsson, A. (2012): Maximizing throughput in finite-source parallel queue systems. European Journal of Operational Research, 217, 554-559. doi: 10.1016/j.ejor.2011.09.041

Douglas, J. ( 1964): Prediction of shovel-truck production: A reconciliation of computer and conventional estimates. Technical report no. 37, Stanford University, California.

Gu, Q. H., Lu, C. W., \& Wan, C. Y. (2008): Monitoring dispatch information system of truck and shovel in an open pit based on GIS/GPS/GPRS. Journal of China University of Mining \& Technology. 18, 288-292. doi: 10.1016/ S1006-1266(08)60061-9

Hartman, H. L. (2002): Introductory mining engineering (second ed.). John Wiley \&Sons, Inc. 138-144 p.

He, M. X., Wei, J. C., Lu, X. M., \& Huang, B. X. (2010): The genetic algorithm for truck dispatching problems in surface mine. Information technology journal. 9, 710-714. doi: 10.3923/itj.2010.710.714

Kaba, F. A., Temeng, V. A., \& Eshun, P. A. (2014): Prediction of mining production using Arena simulation. In: Tarkwa. R, K, Amankwh. (eds.): 3rd UMa T Biennial international mining and mineral conference., 169-177 p.

Kakaee, K., Mirzaee Nasirabad, H., \& Omidabad, M. (2011): Optimization of Shaul-Truck System in Sungun Copper Mine Using Genetic Algorithm. In: Tehran. Taherinejad, N. (eds.): First World Copper Congress., 475-484 p. (Persian Language, with English abstract).

kang, J. H., Ahn, S. M., \& Nam, J. H. (2006): Productivity assessment of rock transportation trucks using simulation technology. In: Tokyo. Zavadskas, E; Kaklauska, A; Skibniewski, M.J. (eds.): Proceeding of the 25th ISARC. - Vilnius Gediminas Technical University Publ. Co., 592-595 p. doi:10.22260/ISARC2006/0111

lizotte, Y., Bonates, E., \& Lecler, A. ( 1987): Design and implementation of a semi-automated truck/shovel. In: Johannsburg. Wade, L; Kersten, R.W.O; Cutland, J.R. (eds.): APCOM 87, 1 . - The Southn African Institute of Mining and Metallurgy Publ. Co., 377-387 p.

Makui, A., Teimoury, E., \& Sarkissian, A. (2010): Development of an open pit transportation mathematical model to improve productivity. International journal of industrial engineering \& production management. 21, 81-92. (Persian Language, with English abstract).

Morgan, W. C., \& Peterson, L. L. (1986): Determining shoveltruck productivity. Mining Engineering, 76-80.

Musingwini, A., \& Krause, C. (2007): Modelling open-pit shovel-truck systems using the Machine Repair Mode. Southern African institute of mining and metallurgy, 107, 469-476.

Nel, S., Kizil, M. S., \& Knights, P. (2011): Improving truckshovel matching. In: Wollongog. Baafe, E. Y; Kininmonth, R. J; Porter, I. (eds.): 35th APCOM symposium. - AusIMM Publ. Co., 381-391 p. 
Rodrigio, M., Fredy, Z., \& Adolfo, A. (2013): Availability-based simulation and optimization modeling framework for open pit mine truck allocation under dynamic constraints. International Journal of Mining Science and Technology. 23, 113-119. doi:10.1016/j.ijmst.2013. 01.017

Sattarvand, A., \& Hashemi, J. (2014): Application of Arena simulation software for evaluation of open-pit mining transportation systems- a case study. In: Aachen. NiemannDelius, C. (eds.): 12th International symposium continuous surface mining. - Springer Publ. Co., 213-224 p. doi: 10.1007/978-3-319-12301-1_20

Subtil, R. F., Silva, D. M., \& Ales, J. C. (2011): A practical approach to trurk Dispatch for open pit mines. In: Wollongog. Baafe, E. Y; Kininmonth, R. J; Porter, I. (eds.): 35th APCOM symposium. - AusIMM Publ. Co., 765-777 p.
Ta, G., Ingolfsson, H. A., \& Doucette, J. (2013): A linear model for surface mining haul truck allocation incorporating shovel idle probabilities. European journal of Operational research. 231, 770-778. doi: DOI: 10.1016/j.ejor.2013.06.016

Yavari , M., Sakkaki, H., \& Shenavar, M. (2005): Semi-automatic system for instantaneous truk send using GPS and wireless in Iran open pit mine. In: Tehran. Ghazvinian, A; Irannejadi, M. (eds.): First Iranian Mining Engineering Conference. - Tarbiat Moddares University Publ. Co., 345-358p. (Persian Language, with English abstract).

Zhang, L., \& Xia, X. (2015): An integer programming approach for Truck-Shovel dispatching problem in Open-Pit mines. In: Abu Dhabi. Yan, J; Shamim, T; Choud, S.k; Li, H. (eds.). 7th International Conference on Applied Energy. - Elsevier Publ. Co., 1779-1789 p. doi:10.1016/j.egypro.2015.07.469

\section{SAŽETAK}

\section{Moguća primjena imperijalnoga natjecateljskog algoritma u rješavanju problema dodjele transportnih vozila procesima na površinskome kopu}

Troškovi transporta na površinskim kopovima vrlo su veliki. Stoga se koriste različite optimizacijske metode. Njihova primjena mnogo je lakša ako su takva vozila uniformna, međutim u suprotnim slučajevima preporučena je uporaba metaheurističkih pristupa. Ovdje je obrađen problem dodjele određenoga broja kamiona svakoj utovarnoj jedinici u rudniku željezne rude. Taj broj određen je uporabom imperijalnoga natjecateljskog algoritma, a u cilju povećanja proizvodnje $\mathrm{u}$ heterogenome okolišu. Zatim je iskorištena funkcija razdiobe kako bi se izračunao iznos proizvodnje tijekom vremenskih razdoblja za odabrani broj transportnih jedinica. Time je simulirano povećanje proizvodnje željezne rude za 4,4 \% te jalovoga ostatka za 4,1 \%. Optimizacijski proces također je omogućio bolju opću kontrolu proizvodnje željeza glede sadržaja fosfornih intruzija.

\section{Ključne riječi:}

otvoreni rudnički kop, utovar, prijevoz, imperijalni natjecateljski algoritam, dodjela resursa

\section{Author's contribution}

Ali Dabbagh, Ph.D. student and Raheb Bagherpour, Associate Professor of Isfahan University of Technology, shared contributions in the theoretical and simulation parts of the paper as well as mine field works. 